\title{
FORMAÇÃO DO AMBIENTE RURAL SUL-MATO-GROSSENSE (1829-1892)
}

\author{
Maria do Carmo Brazil* \\ Elaine Cancian**
}

RESUMO:O presente artigo insere-se no campo da história agrária e visa a refletir sobre a organização da sociedade agropastoril nos campos sulinos de Mato Grosso. Na esteira dos caminhos percorridos por Linhares, através dos campos da história econômica e social, procuramos refletir a forma como os campos de localidades como Santana de Paranaíba, Rio Brilhante, Coxim, Corumbá, Campo Grande e, com destaque, Miranda, se tornaram, entre os anos de 1829 e 1892, importantes marcos da expansão da fronteira fundiária voltada para o centro-oeste brasileiro. Como fontes históricas, recorremos aos itinerários sertanistas oitocentistas, relatos memorialísticos e inventários post-mortem, entre outros documentos, reunidos nos arquivos locais e regionais. Tais materiais evidenciam a concentração fundiária, a exclusão social nela inscrita e dela decorrente, e a montagem de um aparato político repressivo e autoritário, procedimentos oligárquicos também inscritos no processo de ocupação das terras sul-mato-grossenses.

PALAVRASCHAVE: Ruralidade sul-mato-grossense; Oligarquias agrárias; História agrária.

\section{The formation of the rural area in the state of Mato Grosso do Sul (1829-1892)}

ABSTRACT: This paper is included in the field of agrarian history. It aims to investigate the organization of the agricultural society in the southern areas of Mato Grosso. Following the path taken by Linhares, across the fields of economic and social history, we seek to analyze the way such locations as Santana de Paranaíba, Rio Brilhante, Coxim, Corumbá, Campo Grande and mainly Miranda became, between 1829 and 1892, important landmarks in terms of the land frontier expansion towards the Brazilian Center-West region. The historical sources were itineraries written by sertanistas in the $19^{\text {th }}$ century, memorialistic reports and post-mortem inventories, among other documents found in local and regional archives. The materials show the land concentration, the consequent social exclusion, and a repressive and authoritarian political apparatus -oligarchical procedures also included in the process of occupation of the lands in Mato Grosso do Sul.

KEYWORDS: Rural area in Mato Grosso do Sul; Agrarian oligarchies; Lands and historiographical production.

\section{Formación del ambiente rural de Mato Grosso del Sur(1829-1892)}

RESUMEN: Este artículo se enmarca en la historia agraria y tiene como objetivo reflexionar sobre la organización de la sociedad agropecuaria en los campos de Mato Grosso del Sur. Siguiendo los caminos propuestos por Linhares, en las áreas de la historia económica y social, tratamos de analizarcomo los campos Santana Paranaiba, Rio Brilhante, Coxim, Corumbá, Campo Grande y, en especial, Miranda, se han constituyeron entre los años 1829 y 1892, en importantes sitios en la expansión de la frontera terrestre hacia el medio oeste de Brasil. Como fuentes históricas, utilizamos los itinerarios de los exploradores del siglo XIX, las memorias y los inventariospost-mortem, entre otros documentos, depositados en los archivos locales y regionales. Dichos materiales muestran la concentración de tierras, la consecuente exclusión social que se generaba por ello, y el montaje de un aparato político represivo y autoritario, procedimientos oligárquicos también inscritos en el proceso de ocupación de las tierras de Mato Grosso del Sur.

PALABRASCLAVE: Ruralidadde Mato Grosso del Sur; Oligarquías agrarias; Historia agraria.

\footnotetext{
*Doutora em História Social pela Universidade de São Paulo (1999). Professora Titular em História do Brasil da Universidade Federal da Grande Dourados .E-mail: mc.2708@hotmail.com.

**Docente do curso de Licenciatura em História do Campus do Pantanal (CPAN /UFMS).
} 
O presente artigo inscreve-se na corrente de esforços acadêmicos empreendidos no período de fins dos anos 1960 e início dos anos 1970, quando pesquisadores como Maria Sylvia de Carvalho Franco (1969), José de Souza Martins (1979) e Maria Yedda Linhares e Francisco Carlos Teixeira da Silva $(1981)^{1}$ encetaram as primeiras trilhas que levariam ao entendimento de parte da ruralidade brasileira e à construção dos alicerces da moderna história agrária do Brasil. As pesquisas efetivadas principalmente por esses estudiosos, com destaque para Linhares, diversificaram as interpretações sobre o Brasil nas suas diferentes paisagens agrárias, a partir de matrizes históricas decisivas no que diz respeito à relação propriedade/trabalho.

Maria Yedda Linhares, precursora da história agrária moderna, colaborou com a orientação de vários trabalhos acadêmicos relacionados ao espaço rural. Uma das primeiras produções foi a dissertação escrita por João Luiz Ribeiro Fragoso, defendida em 1974na Universidade Federal do Rio de Janeiro, intitulada "Sistemas Agrários em Paraíba do Sul um estudo das relações não capitalistas de produção"2. O texto de Fragoso abriu perspectivas para a investigação acadêmica, de forma que,nos anos 1980, outros pesquisadores voltaram-se à temática da estrutura agrária, sobressaindo-se Hebe Maria da Costa Mattos Gomes de Castro, Maria Paula Granere Sheila Siqueira de Castro Faria ${ }^{3}$. Estes estudiosos, orientados por Linhares, diversificaram os temas relacionados à terra,dedicando-se a questões como o trabalho no campo, a ocupação pastoril eo arrendamento de terras, entre outras.

No iníciodos anos 1990, emergiram as teses e dissertações também orientadas por Linhares, com distinção para Eliana Vinhaes, João Antônio Botelho Lucídio, Márcia Maria Mendes Motta e Sheila Siqueira de Castro Faria ${ }^{4}$. Alguns desses estudiosos, depois de integrados em instituições de ensino superior, ajudaram a despertar interesses de mestrandos e doutorandos na execução de trabalhos sobre o mundo rural. Estimulados por essa segunda geração de pesquisadores, em meados dos anos 1990, Edval de Souza Barros, Helen Osório, Ricardo Muniz Ruize Mônica Ribeiro de Oliveira ${ }^{5}$ investigaram problemas relacionados ao universo rural oitocentista do Rio Grande do Sul, antes interpretado pelo viés da historiografia tradicional.

Recentemente, com o desenvolvimento de pesquisas inovadoras, promovidas pelos programas de pós-graduação das Instituições de Ensino Superior-IES, os espaços rurais do sul brasileiro passaram a ser estudados em suas singularidades, a partir da crítica aos pressupostos lançados pela historiografia tradicional. Investigadores como Cristiano Luiz Cristillino (2010), GracielaBonassa Garcia (2010) e demais pesquisadores engajados nos estudos sobre a 
ruralidade brasileira ${ }^{6}$, integrados nos cursos de pós-graduação, como apenas assinalado, deram o tom da mudança, colaborando na definição do novo quadro do universo rural do Brasil.

Relativo ao ambiente rural do sul de Mato Grosso, no que se refere à organização da sociedade agropastoril,as análises foram conduzidas, portanto, a partir dos estudos de João Antônio Botelho Lucídio, na dissertação "Nos confins do Império um deserto de homens povoado por bois: a ocupação do Planalto Sul Mato Grosso, 1830-1870”, defendida nos idos de 1993, junto ao Programa de Pós-Graduação em História pela Universidade Federal Fluminense/UFF. À época,era grande o desafio de se obterem fontes sobre o passado agrário brasileiro. Tal dificuldade ampliava-se quando se decidia estudar a organização da sociedade da parte interna do país. Isso porque o historiador, em primeira instância, precisava "descobrir" onde estavam essas fontes para, então, interpretá-las.Nas palavras de Lucídio, "[...] o desafio estava lançado e as fontes mais usais de fato exíguas". 7

Se a carência de estudos envolvendo a dinâmica agrária no Brasil ainda é grande, a questão torna-se mais grave em âmbito regional, com ênfase para as particularidades dos campos sulinos de Mato Grosso (unificado). O cotejamento dos estudos efetuados por historiadores mato-grossenses e a disposição do elenco de fontes históricas "descobertas" a partir do final dos anos 1970 evidenciaram o dramático "emudecimento" historiográfico sobre a complexidade da estrutura agrária e das condições sócio rurais. Tal estrutura era constituída não só por segmentos escravizados, mas por vários agentes sociais imbuídos de interesses diversos, práticas econômicas e comerciais variadas, modos distintos de produzir e manter a terra, enfim, formas de viver, sobreviver e de agir diferenciadas.

Nos anos 1980, influenciados pelos novos estudos sobre a escravidão brasileira da década anterior, que abordavam temas e espaços sobre o universo agrário, pesquisadores em distintas Instituições de Ensino Superior no país impulsionaram a produção sobre a relação escravista na região. Potenciados pelas comemorações do primeiro centenário da Abolição (1988), publicaram-se artigos, livros, dissertações e teses sobre a escravidão em Mato Grosso.

Desse esforço, emergiu significativo volume de pesquisa em Mato Grosso acerca do trabalho escravizado. No entanto, a respeito do trabalhador livre, sob o estatuto da escravidão, a abordagem mostrou-se inegavelmente limitada. No rol das exceções, em 1984 a historiadora Lúcia Helena Gaeta Aleixo trouxe a público "Mato Grosso: trabalho escravo e trabalho livre (1850-1888)", , o primeiro livro regional sobre relações de trabalho (livre e escravizado) oriundo de resultados de pesquisa acadêmica. 
Merece realce a produção de Luiza Rios Ricci Volpato, "Cativos do Sertão. Vida quotidiana e escravidão em Cuiabá em 1850-1888", de 1993, que fez emergir da documentação compulsada nos arquivos regionais a vida cotidiana de homens livres e escravizados, permitindo que histórias de "pessoas anônimas que jaziam adormecidas nas caixas e livros dos arquivos pudessem ser recompostas e reescritas". 9

Diante da expansão e do fortalecimento dos Programas de Pós-Graduação no Brasil, intensificaram-se, no período 2000-2010, novos trabalhos relevantes dedicados aos temas ligados à economia e à história da escravidão em Mato Grosso, mas ainda era muito restrita a abordagem sobre o universo agrário de sua parte sulina. A despeito da escassez de trabalhos voltados para Mato Grosso, com temática sobre a terra e as relações de trabalho, veio a lume aobra“Terra e Poder em Mato Grosso.Política e mecanismos de burla1892-1992”, 2007, uma importante contribuição de Gislaene Moreno ${ }^{10}$, cuja abordagem inclui cenários, personagens, o papel das elites regionais no contexto da conquista, ocupação, disputa e formação do território mato-grossense.

Outra contribuição foi a publicação de obras organizadas por Maestri. "Peões, vaqueiros \& cativos campeiros: estudos sobre a economia pastoril no Brasil", foiproduzida em três tomos ${ }^{11}$, fruto do desenvolvimento do Projeto "A produção pastoril no Piauí, no Mato Grosso e no Rio Grande do Sul, de 1780 a 1930: um estudo comparado”, desenvolvido entre os anos de 2007 e 2009. Além disso, a pesquisa sobre o passado pastoril ganhou impulso e acolhimento, graças ao seu caráter nacional e regional, e gerou o dossiê intitulado "A fazenda pastoril e a escravidão" da revista "História: Debates e Tendência", reunindo trabalhos centrados no Rio Grande do Sul, Piauí e Mato Grosso. ${ }^{12}$

Além da produção de João Lucídio (1993) já citada, os trabalhos elaborados por historiadores como Brazil (2009), Cancian (2014), Camargo (2010) e Rodrigues $(2014)^{13}$ podem ser apontados como as primeiras aproximações com a temática acerca do apossamento, do aproveitamento agrícola e da concentração fundiária de Mato Grosso no século XIX, no contexto da formação da sociedade brasileira.

\section{Rumo aos campos sulinos de Mato Grosso}

A historiografia regional mostra que a região de Santanade Paranaíba, além de via de penetração para os Campos de Vacaria, era primordialmente habitada por ameríndios do grupo linguístico Jê - os caiapós. Entre os anos de 1739 e 1755, o espaço tornou-se bastante 
frequentado pelas expedições paulistas, que tinham como objetivo a captura de nativos para escravização. ${ }^{14}$ Apenas em 1829 ocorreu a chegada de ocupantes "não nativos", oriundos de Minas Gerais e Franca (SP), como as famílias Garcia Leal, Rodrigues da Costa, Correia Neves, Barbosa e Lopes. Segundo Isabel Camargo, não obstante a presença dos naturais da terra, foi atribuída aos entrantes oitocentistas a posição de "desbravadores", de primeiros ocupantes ou "pioneiros”.Procedentes do interior de São Paulo, do Triângulo Mineiro, Paraná e Goiás, chegaram de carreta e a cavalo para ocupar o espaço dito "desabitado". Minas tornou-se uma das principais regiões provedoras de bovino destinado ao melhoramento daquele gado remanescente do passado missioneiro (período colonial). ${ }^{15}$

Essa corrente migratória penetrou na Província através de Santana de Paranaíba (sertão dos Garcia). Desse ponto, expandiu-se em direção ao interior da parte sul da Província de Mato Grosso, abrangendo a região conhecida como Campos de Vacaria e, mais tarde, alcançou também a região de Campo Grande, hoje capital de Mato Grosso do Sul, cuja toponímia revela seu passado pastoril. Na figura 1, observamos a localização do território em questão.

Figura 1. Região da Vacaria



Fonte: "Localização dos campos de Vacaria de Mato Grosso e da rota da expedição de Joaquim Francisco Lopes realizada em 1847, partindo vale do Rio Tibagi (PR) rumo aos Campos de Miranda (MT)". Fonte: BRAZIL, M. do C. Sobre os campos de Vacaria do Sul de Mato Grosso: considerações sobre a terra e escravidão (1830-1889), p. 225. In: MAESTRI, Mário; BRAZIL, Maria do Carmo. Peões, vaqueiros \& cativos campeiros: Estudos sobre a economia pastoril no Brasil. Passo Fundo: Ed. Universidade de Passo Fundo, 2009. p. 219-250. (Coleção Malungo, 17). p. 238. Mapa disponível em: http://do.ufgd.edu.br/OmarDaniel. Acesso em: fevereiro de 2014.

As terras integrantes do patrimônio das famílias ocupantes do sul de Mato Grosso basearam-se no sistema sesmeiro, que se estendeu pelos atuais municípios da região. Imensas propriedades pastoris formaram-se, conforme explicitamos, sob o domínio desses migrantes oriundos de Minas Gerais. Arraiais, vilas e cidades desenvolveram-se a partir da construção 
de inúmeros ranchos, erguidos rusticamente nas barrancas de rios inexplorados ou nas vizinhanças de vendas, tabernas ou pousos construídos em curvas de estradas.

Nos anos que antecederam a promulgação da Lei de Terras de 1850, em bandeira expansionista, oficialmente autorizada pelo Vice-Presidente da Província de Mato Grosso Tenente Coronel Jerônimo Joaquim Nunes, o mineiro Joaquim Francisco Lopes e o norte americano João Henrique Elliott, munidos de escravizados "camaradas, mantimentos, e todos os mais auxílios precisos, empenharam-se na exploração das terras mato-grossense". ${ }^{16}$ José Garcia e Januário Garcia Leal tornaram-se os principais expoentes dessa frente de ocupação. Joaquim Francisco Lopes foi líder das inúmeras expedições rumo ao oeste de Mato Grosso, tanto para servir aos intentos governamentais como também para atender aos interesses fundiários de João da Silva Machado, o barão de Antonina. ${ }^{17}$

O barão de Antonina, vulto proeminente da região do Paraná da segunda metade do século 19, procurou legitimar (na forma de propriedade privada) a posse do território que abrangia a região de Santana de Paranaíba, Rio Brilhante, Miranda, Nioac, Aquidauana, Ponta Porã, Porto Murtinho e Bela Vista. Além disso, o barão apossou-se de vastas áreas do Norte do Paraná, diversas fazendas em São Paulo e em outros estados, tudo isso representando apenas uma parcela do seu vasto patrimônio fundiário. Na porção sul de Mato Grosso, é pertinente o exemplo de sérias demandas judiciais envolvendo o barão, cuja acumulação de terras ocorria através de procedimentos refutados judicialmente nos anos 1920, diante da constatação de que se tratava de um processo de amigos e compadres. ${ }^{18}$

Em estudo dedicado aos empreendimentos do barão de Antonina, Maria Cristina Cortez Wissenbach narrou que, entre os anos de 1844 e 1857, os ditos sertanistas empreenderam expedições rumo ao sul do antigo Mato Grosso: "percorreram, sob orientação do barão, os rios Verde, Tibagi e Paranapanema, na antiga província de São Paulo, navegaram trechos do 'Grande Paraná', e através de seus afluentes da margem direita, Ivinhema, Iguatemi, Brilhante e Dourados, penetraram na região sul de Mato Grosso"19. Grande parte dessas regiões ricas em campos e pastos foi marcada como posses territoriais do barão de Antonina, pouco antes da efetivação da Lei de Terras de 1850.

Concorrendo com as ambições fundiárias do barão de Antonina, estavam os interesses dos Garcia Leal, dos Ferreira de Melo, dos Gonçalves Barbosa e dos próprios Lopes, com destaque para Gabriel Francisco Lopes que, segundo Mario Monteiro de Almeida, "se fez senhor de terras ilimitadas". Ou seja, "como de prática corrente, nessa época e entre esses 
desbravadores dos sertões mato-grossenses converteu o descobrimento em fonte de renda pela alienação de glebas, ou de posses feitas, na predita forma de improvisação". ${ }^{20}$

As investidas dos Lopes, dos Garcia Leal e dos Barbosa, a partir do final dos anos 1820, representam exemplos emblemáticos da prática do apossamento livre. A leitura atenta das suas atividades no território em questão sugere como os exploradores oitocentistas dos sertões se apossavam de terras ou "faziam as posses". Tais famílias migraram no período "áureo do posseiro" (1822-1850), bem no momento em que a posse, logo após a independência política do Brasil (1822), setornou a única forma de aquisição de domínio sobre as terras. Portanto, a aquisição de terras e a expansão territorial estiveram garantidas com o apossamento e o trabalho nas propriedades assentadas no regime escravizado. $\mathrm{O}$ quadro favorável aos proprietários rurais mantinha-os alheios à necessidade de leis destinadas à regulamentação da posse territorial. Autores como Lígia Osório Silva (2008) e Marcia Motta $(2008)^{21}$ indicaram que a prática de apossamento livre sobreviveu aos decretos, leis e regulamentos instituídos no Brasil colonial, atravessaram os tempos, predominando na primeira metade do século 19. Nesse contexto de referências voltadas à posse livre, ocorreu a ocupação das terras do atual Mato Grosso do Sul, antiga porção sul da província de Mato Grosso.

A Lei de Sesmarias perdurou até o Primeiro Reinado, quando foi revogada pela Resolução 76 de Consulta da Mesa de Desembargo do Paço, de 17 de julho de 1822, que "Manda suspender concessão de sesmarias futuras até a convocação da Assembléia Geral Constituinte" 22 . Para Ruy Cirne Lima, depois de revogada a Lei de Sesmarias, a humilde posse com cultura efetiva se impregnou do espírito latifundiário e as posses passaram a abranger fazendas inteiras, com léguas a fio. ${ }^{23}$

Após a abolição da referida lei, nada foi pensado para substituí-la, criando-se um vazio jurídico pela posse da terra. Entretanto, esse importante viabilizador do processo de apropriação do território, o sistema sesmarial, abolido às vésperas da Independência, ainda hoje causa inegável impacto sobre a estrutura fundiária do país.

Foi nesse cenário, durante o período de posses livres, entre a revogação da Lei de Sesmarias em 1822 e a aprovação da Lei de Terras em 1850, que os consórcios dos Garcia e dos Lopes ocuparam extensas áreas na região de Santana do Paranaíba. A posse da terra deu a essas famílias status, poder e proximidade com as autoridades provinciais, quando da ocupação dos "deslumbrantes campos promissores", conforme expressão usada por 
VirgílioCorrêa Filho para designar a expansão bandeirante após a criação da Capitania de Mato Grosso ${ }^{24}$.

Em 1892 ocorreu a promulgação da primeira lei de terras estadual, seguida do estabelecimento de ações, pelo governo local, voltadas à regularização das propriedades particulares localizadas no espaço territorial do estado de Mato Grosso. A análise exige detida atenção sobre a Lei de Terras de 1850, porque vigorou até a promulgação da primeira Constituição Republicana em 1891, quando ocorreu a implantação do sistema federativo no Brasil. A partir de 1892, ficou delegada aos estados a responsabilidade sobre as terras devolutas de seus territórios, ou seja, cada estado passou a legislar em função da organização dos seus espaços. Com relação a Mato Grosso, foi estabelecida a primeira lei estadual $\left(n^{\circ} 20\right.$, de 9 de novembro de 1892), dispondo sobre os processos de revalidação, legitimação e venda de terras no estado, que foi regulamentada pelo Decreto n. 38, de 15 de fevereiro de 1893.

Em âmbito nacional, sobretudo no nordeste, os diversos relatos oficiais ressaltam o papel de algumas famílias que se aventuraram pelo interior brasileiro e garantiram o domínio das terras a partir da expansão dos currais $^{27}$, à custa de estratégias políticas de aquisição, manutenção e ampliação do patrimônio, recorrendo, não raro, a procedimentos fraudulentos. ${ }^{26}$ Algumas fontes referentes às questões de terras ${ }^{27}$ evidenciam principalmente a importância das "famílias pioneiras" na conquista e na incorporação de vastas extensões de terra ao corpo da nação brasileira. Mas a dificuldade de calcular o tamanho dos latifúndios, graças à imprecisão e à falta de clareza da fiscalização, deu origem a inúmeras demandas judiciais que alcançam os dias atuais. ${ }^{28}$

\section{A ruralidade nos campos sulinos de Mato Grosso.}

Mário Monteiro de Almeida,em Episódios da formação geográfica do Brasil,1951, ${ }^{29}$ contou que,nos anos 1830 , três famílias de mineiros e francanos conquistaram a enorme área do sudeste do antigo Mato Grosso: os Garcia Leal, os Barbosa e os Lopes. Sobre a questão,assim se expressou:

Antonio Gonçalves Barbosa era tronco de família numerosa. Mais de duas dezenas de descendentes lhe enriqueceriam o lar, unido sob o dominante regime coevo de educação severa. Uma de suas filhas, Senhorinha Maria daConceição Barbosa casou-se com Gabriel Francisco Lopes. Outra Maria Antonia de Jesus Barbosa consorciou-se com Tomaz Ferreira de Melo, filho de Joaquim Ferreira de Melo, um dos irmãos fundadores de Campo Triste. Antonio Candido de Oliveira casou-se com outra filha do operoso desbravador, Maria Rosa de Jesus Barbosa. Ao lado de filhos operosos e dinâmicos, o intrépido povoador de Franca procriara uma coleção de Marias fecundas e diligentes. A sua descendência, em meados do século, já se computaria por inúmeros sertanistas. ${ }^{30}$ 
A partir da atuação dos líderes como José Garcia e Januário Garcia Leal, ocorreu a expansão de uma corrente "[...] em direção ao interior da parte sul da província, abrangendo a conhecida campos de Vacaria e, mais tarde, a região de Campo Grande, hoje capital de Mato Grosso do Sul, cuja toponímia revela seu passado pastoril”. ${ }^{31} \mathrm{Na}$ figura 2,temos o mapa desenvolvido especialmente para mostrar a região penetrada a partir de 1830.

Figura 2. Território de Santana de Paranaíba ocupado por famílias de mineiros e francanos.

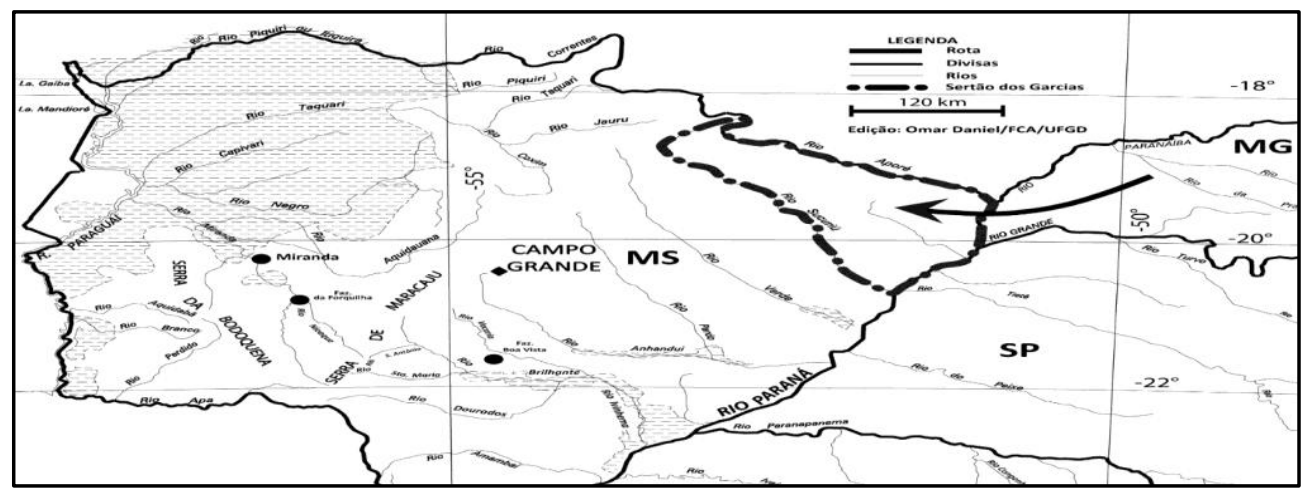

Figura 2: Região de Santana de Paranaíba - Sertão dos Garcia. Fonte: BRAZIL, Maria do Carmo. Sobre os campos de vacaria do sul de Mato Grosso: Considerações sobre a terra e escravidão (1830-1889). In: MAESTRI, Mário; BRAZIL, Maria do Carmo. Peões, vaqueiros \& cativos campeiros: Estudos sobre a economia pastoril no Brasil. Passo Fundo: Ed. Universidade de Passo Fundo, 2009. p. 219-250. (Coleção Malungo, 17).

Em 1836, na região de Santana de Paranaíba,erigiu-se a primeira igreja, graças à iniciativa da família Garcia e do padre Francisco Sales de Souza Fleury. Este último, investido no cargo de capelão, era encarregado da assistência espiritual aos ocupantes dos sertões devolutos de Santana, como assinalado, porta de entrada para os Campos de Vacaria.

Observe-se que a antiga região dosul de Mato Grosso era uma fronteira flutuante ${ }^{32}$, disputada por redes internas e externas de povoamento. $\mathrm{Na}$ região em questão, uma vez realizada a ocupação, foram implantadas as estruturas políticas e eclesiásticas, movidas por funcionários, proprietários e padres que agiam comochefes políticos, que disputavam poder com fazendeiros ou se inseriam no seio desse segmento, concorrendo ao mando local. Da documentação sobre as cartas de alforrias contidas no livro "Como se de ventre livre nascido fosse" ${ }^{33}$, emerge o pároco Francisco de Sales Souza Fleury, natural da cidade de Franca, interior de São Paulo que, nos anos 1830, se fixou no povoado de Santana de Paranaíba. O padre teria exercido grande poder senhorial, sobretudo no que se referia à política local, terras, cativos, agregados e homens livres de poucas posses ${ }^{34}$. Ao defender seus próprios interesses, 
os párocos eram responsáveis pela realização de casamentos, batizados, rezas e missas, cerimônias religiosas que ensejavam relações inter-senhoriais, manifestações de poder e autoridade sobre os segmentos subalternizados. ${ }^{35}$ Fleury, por exemplo, mediou inúmeros processos de manumissões incluídos em heranças de famílias escravizadoras regionais, como a de José Garcia Leal e a de dona Maria Garcia Tosta. ${ }^{36}$

A força política do padre Fleury tornou-se mais visível com o processo de superação do escravismo, desencadeado a partir de 1850, quando os escravizadores tinham de realizar Matrícula Especial dos escravizados, nas coletorias constituídas pelo Promotor Público, pelo Coletor e pelo presidente da Câmara ${ }^{37}$. Para completar as informações prestadas pelos escravizadores, os párocos deviam fornecer dados sobre os nascimentos e os óbitos de cativos. De acordo com os relatos de Justiniano Fleury ${ }^{38}$, nos anos de conformação da sociedade santanense, outros eclesiásticos se projetaram e adquiriram imenso poder político local, graças às autorizações assinadas pelo Bispo de Cuiabá:

\begin{abstract}
O Padre Francisco de Salles Fleury; o primeiro professor publico e escrivão do Juízo de Paz e da Sub-Delegacia de policia Luiz Beltrão de Souza, irmão do mesmo vigário; primeiro collector e Agente do correio, José Ruiz Anacleto, genro do capitão Garcia; primeiro director dos índios Cayapós, aldeiados à margem direita do rio Paraná, junto salto grande do Urubupungá, o capitão José Garcia Leal; primeiro Juiz de Paz, o capitão Jose Coelho de Souza, e primeiro sub-delegado Joaquim Limos da Silva. ${ }^{39}$
\end{abstract}

Entre os cargos que deram poder ao vigário,sobressaíram-se o de inspetor paroquial de instrução pública primária e o de capelão local, oferecendo "assistência espiritual aos ocupantes dos sertões devolutos de Santana de Paranaíba ${ }^{40 "}$. Isso atribuiu a Fleury o papel de ativo intermediador de alforrias, de suma importância para o segmento proprietário, como mencionado.

Proprietários como Luiz da Costa Falcão, da região Miranda, adquiriam terras a partir da obtenção de posses dos primeiros ocupantes, cuja regulamentação se deu na segunda metade do século 19, pelos preceitos do Decreto instituído em 30 de janeiro de 1854. Helen Ortiz explicou que, através do referido regulamento, o Império executava a legislação sobre terras, considerando os capítulos e os artigos que tratavam de itens como medição, revalidação e legitimação de domínios públicos e particulares. O Decreto de 30 de janeiro de 1830 também tratava da questão de venda, conservação das terras devolutas e determinação de procedimentos de registro das terras possuídas ${ }^{41}$. O órgão destinado à execução desse regulamento era a Repartição Geral das Terras Públicas, subordinado ao Ministério e 
Secretário de Estado dos Negócios do Império, sendo chefiada por um Diretor Geral das Terras Públicas. ${ }^{42}$

É preciso expor que, além dos entrantes francanos, mineiros e paranaenses, outra corrente oriunda do oeste de Mato Grosso afluiu para o sul da província mato-grossense, com o episódio da Rusga. Esse movimento ocorreu em 30 de maio de 1834, em Cuiabá, capital da província de Mato Grosso e tratou-se de:

luta política intestina travada entre integrantes da burguesia comercial, aparentemente determinada pelas origens nacionais do movimento nativista. De um lado encontrava-se o grupo formado pelos comerciantes portugueses, que historicamente dominavam o comércio da região, desde a mineração, e de outro, os comerciantes nativistas, que se sentiam espoliados pelo outro grupo. ${ }^{43}$

Participantes da Rusga violaram as casas comerciais e assassinaram portugueses. Repreendidos pelo governo, deixaram os limites de Cuiabá em direção ao sul da província. Com o propósito de se resguardarem, procuraram terrenos distantes, como a região do vale do Taboco, do rio Negro, Nioaque, Aquidauana e Miranda. Nessas paragens, apossaram-se de terras e formaram grandes propriedades rurais.

Os entrantes de Cuiabá, ao se apossarem de extensas porções de terras no vale do Taboco e do rio Negro, expandiram-se em direção ao território de Miranda. Por meio das relações parentais, escravistas e de camaradagem, a frente migratória oriunda de Minas Gerais, ao adentrar pelos campos da Vacaria,reuniu-seaos migrantes cuiabanos.Mário Monteiro de Almeida, na obra“Episódios Históricos da Formação Geográfica do Brasil”, 1951,sugeriu que as duas correntes migratórias se encontraram em 1844. Registrou sobre a questão:

Foi no vale do Miranda e dos tributários de sua margem direita, a sudeste do presídio, que se verificou, por volta de 1844, o contato das duas correntes de povoadores, a procedente de Cuiabá, que antecedera, e a subsequente, originária de Minas e das terras paulistas limítrofes das mineiras, em especial de Franca, vila próxima dos sertões de Farinha Pôdre. ${ }^{44}$

A considerar as informações de Mário Monteiro, desde 1833 as terras limítrofes, às margens do rio Miranda, já estavam ocupadas por algumas famílias envolvidas nas atividades rurais. Para citar alguns exemplos, citamos Caetano da Silva Albuquerque, João Canuto Cordeiro de Faria, João de Faria Velho, João Mamede, José Francisco Lopes, Luís Generoso de Albuquerque e Maria Domingas de Faria, todos dedicados ao cultivo de alimentos e à criação de animais. ${ }^{45}$ 
Por meiode documentação específica constante em pesquisa sobre o processo de ocupação de terras e a formação e legalização das propriedades rurais do território de Miranda, de 1830 a 1892, para onde afluíram algumas famílias de migrantes, obtivemos informações preciosas relativas à constituição de posses. As investigações mostraram que determinadas glebas foram ocupadas desde 1830. Todavia, é relevante aventar a possiblidade de uso da terra nessas paragens desde o final do século 18 e início do século 19 , devido à presença do presídio de Miranda, elevado em 1797 às margens do rio homônimo. ${ }^{46}$

Àmedida que as famílias de migrantes foram se apossando livremente das terras consideradas devolutas e alargando as suas fazendas pelas matas e terras alagadiças dos pantanais, tornaram-se grandes proprietárias de posses confrontantes no território de Miranda. As fazendas formadas na região tinham proporções tão amplas que promoveram, ainda na primeira metade do século 19, o encontro dos fazendeiros geralistas e cuiabanos.

Para Mário Monteiro, o território de Miranda, até à época da ocupação das terras por famílias provindas de outras partes do império brasileiro, permaneceu em estado selvático.O autor desconsiderou as atividades desenvolvidas por indígenas e outros poucos habitantes instalados na região em decorrência da fundação do forte de Miranda, em $1776 .{ }^{47}$ Todavia, o viajante Luiz D'Alincourt atestou que,desde 1826, havia indivíduos empenhados na criação de gado vacum e na plantação de cereais, sobretudo nas cercanias do presídio de Miranda. Assim, o deslocamento de famílias oriundas de Cuiabá e Santana de Paranaíba promoveu, com certa intensidade, a ocupação do território mirandense, a partir do apossamento de grandes extensões de terras.Mas a prática do plantio e da lida com os animais comprovou-se mais remota. ${ }^{48}$

Algumas das famílias estabelecidas ao sul da província de Mato Grosso envolveram-se com a criação de animais. Outras se dedicaram ao cultivo da cana-de-açúcar e à fabricação de seus derivados. Porém, a caça de animais também atraiu os primeiros povoadores das terras mato-grossenses. Sobre o exercício da atividade de caça, Mário Monteiro escreveu:

\footnotetext{
Povoadores penetraram nas terras insuladas com objetivos venatórios, profissionalmente exercidos. Superabundavam, em quantidades imensas, nos vales do Miranda e de seus tributários, como no altiplano da serra de Amambaí, em derredor do Ivinhema e de seus tributários, todas as qualidades de caças de pelo e de asas, inclusive os cervos e veados de características diferentes. ${ }^{49}$
}

Conforme Almeida, a atividade de caça rendia ganho superior, quando comparado ao lucro retirado do plantio da cana-de-açúcar e da produção do sal. Os caçadores de cervos 
procuravam áreas estratégicas para alcançar as populações desses animais. Assim, atingiam locais como a "zona subterrana, onde as águas salobras constituíam pontos de preferência para as diversas espécies de animais de pêlo se dessedentarem, afluíam os veados brancos [...], como alí e principalmente no planalto serrano, o galheiro". 50

As peles dos cervos serviam de matéria-prima na preparação de arreios, selas e demais artefatos usados pelos tropeiros da época durante as longas viagens pelos sertões. Sobretudo os geralistas e paulistas, que se deslocavam continuamente em longas trajetórias pelos sertões, davam preferência aos petrechos feitos com o couro de cervo. As garças também eram alvos dos caçadores, que procuravam por seus bandos nas águas pantaneiras. As suas plumas brancas eram empregadas na moda feminina, sobretudo na feitura de chapéus. Almeida descreveu: "Abundavam ali as formosas e ariscas aves, em cuja caça os profissionais empregavam, por vezes, ardís e estratagemas laboriosos, e entre eles os da dissimulação de sua presença próxima, nas águas pantanosas, em cuja vizinhança as garças se aglomeravam em bandos". 51

\section{Água, barreiro e capim}

As áreas ocupadas pelos proprietários rurais dos pantanais, oriundos de Cuiabá, eram abundantes em água, barreiros, capim mimoso e demais gramíneas favoráveis à alimentação dos animais. Para Virgílio Corrêa Filho, em "Monografias cuiabanas", 2002, os criadores adequaram a sua tradição na lida com o gado às condições naturais das novas terras apossadas, "aceitando a colaboração dos agentes naturais", de tal forma que, no período do alagamento das áreas ocupadas, o gado era levado aos campos firmes e ao cerrado e reconduzidoaos pantanais, após o término do ciclo das chuvas, quando a pastaria reaparecia. ${ }^{52}$

Para Corrêa Filho, a criação de gado nas áreas dos pantanais não exigia grandes esforços dos criadores, que "[...] confiavam à natureza, que entrou a atuar de maneira acentuada, promovendo a formação da variedade pantaneira, de couro grosso, resistente às intempéries e aos mosquitos, e afeita à luta contra as águas, em que vive grande parte do ano”. Assim, excetuando-se a atividade de deslocamento do gado em período das cheias, o proprietário rural preocupava-se com a marcação, a castração e a ferra. As crias novas eram marcadas “[...] com o sinal nas orelhas, por meio de cortes e recortes", e a castração era feita nos marruás e tourinhos. Tais atividades eram praticadas quase exclusivamente pelos vaqueiros, que "[...] passavam dias e noites dormindo ao léu, para cortar a batida de manadas ariscas e retardatárias, em campeios aguçadores dos seus sentidos". 53 
Ainda conforme Corrêa Filho, diferentemente dos criadores dos pantanais, os fazendeiros oriundos de Minas Gerais, apesar de disporem de extensas propriedades, criavam uma quantidade reduzida de rebanho bovino, devido à dificuldade na obtenção de sal. Sobre a questão, registrou:

Debalde se procuraria nessas encantadoras paragens, alguma fazenda povoada de milhares de cabeças bovinas. As despesas causadas pelas salgas não permitiam o aumento ilimitado dos rebanhos, como era comum nos pantanais, onde a percentagem anual de colheita oscilava em torno de $25 \%$, calculada sobre o total dos rodeios, quando não os dizimava a enchente, insulando-os em redutos, que as águas constringiam progressivamente, submergindo as pastagens, ao extremo de privá-los de qualquer alimento. ${ }^{54}$

O historiador sul-mato-grossense Paulo Marcos Esselin, no texto "A pecuária bovina e o processo de ocupação do Pantanal Sul-mato-grossense", também ponderou sobre a existência dos rebanhos de animais alçados, as extensas terras devolutas com pastagens nativas e os barreiros e as baías com águas salobras, grandes atrativos às famílias participantes das duas frentes migratórias. Para o autor, a grande quantidade de gado vacum e cavalar, espalhada pelas terras alagáveis, foi fator decisivo na escolha entre o Planalto e o Pantanal, “[...] pois com esses animais foi possível organizar as primeiras propriedades: 0 gado foi sendo amansado, o couro era a principal mercadoria de troca e a carne seca também oferecia alguns recursos para os pioneiros". 55

\section{"Fazer posses" em terras mato-grossenses}

Os migrantes cuiabanos, geralistas e paulistas tornaram-se proprietários das terras localizadas ao sul da província de Mato Grosso, colocando em prática o apossamento livre, ou seja, a demarcação dos terrenos destinados à fundação da propriedade rural. Tal ato era baseado em costume bastante antigo, surgido ainda no passado colonial. Também denominada de posse pura e simples, permaneceu concomitante à forma de apropriação territorial, instituída pela Coroa portuguesa por meio de decretos, leis e regulamentos. Assim, desde os primórdios da colonização, subsistiram o sistema sesmarial e o apossamento livre.

Nas memórias do sertanista Joaquim Francisco Lopes, encontramos informações sobre a forma de "fazer posses", ou seja, como os sertanistas e migrantes oitocentistas se apossavam de extensas glebas em território sul-mato-grossense. Conforme os registros deixados por Lopes, os indivíduos acompanhavam as trajetórias dos rios, adentravam os matagais, observavam as peculiaridades naturais dos terrenos ainda inexplorados por luso-brasileiros, marcavam "a olho" a gleba escolhida e, por vezes, plantavam roças no local. Como exemplo 
da empreitada, mencionamos algumas viagens empreendidas por Joaquim Francisco, que resultaram no apossamento livre de algumas áreas.

Em "As derrotas de Joaquim Francisco Lopes", consta que, no ano de 1831, o sertanista citado, acompanhado por José Garcia Leal e quatro camaradas chamados Alexandre, Antônio, Barbosa e Inácio, navegaram o rio Paranaíba acima.Ao chegarem a um lugar firme, chamado de Santa Ana, plantaram roça com o objetivo de "formar a nova situação do dito Garcia”. Em julho do mesmo ano, Joaquim Francisco Lopes, na companhia de seu pai, Antônio Francisco Lopes, e seus irmãos João, José e Manuel, com mais dois cativos e dois camaradas, com o objetivo de descobrir o rio Verde, subiram o ribeirão de Santa Quitéria, para ter acesso a uma fazenda apossada por Garcia Leal e doada a Antônio Lopes, em cuja posse plantaram roça. Em prosseguimento à viagem, fizeram posse na margem direita do rio Sucuriú. Ao atingirem as terras banhadas pelo rio Verde, subiram o rio e, durante três dias de deslocamento, foram "aposseando de um e outro lado". Na margem direita do rio Verde, fizeram posses Joaquim Francisco Lopes, junto ao irmão Manuel e o cativo Vicente. Na esquerda, seguiram fazendo posses Antônio Francisco Lopes, seu filho João, o cativo sapateiro Francisco e o camarada Manuel Pião. ${ }^{56}$

As terras demarcadas 'a olho', quando não ocupadas pelos próprios demarcantes, serviram para presentear membros familiares ou agregados e demais conhecidos, por serviços prestados. A prática da comercialização das terras ocupadas livremente também ocorria. Dessa forma, grandes extensões de terras foram sendo ocupadas por indivíduos conhecidos ou de uma mesma família. A exemplo, temos os sertanistas Joaquim Francisco Lopes e José Garcia Leal que, uma vez conhecedores do território mato-grossenses e hábeis "fazedores de posses", propiciaram terras aos amigos, companheiros e familiares. Daí terem se espalhado pelo território do sul da província de Mato Grosso, como proprietários de posses e criadores de gado. Semelhantemente às famílias Garcia e Lopes, outros chefes oitocentistas procederam à escolha e à demarcação a olho das terras do atual Mato Grosso do Sul, onde desenvolveram atividades de cultivo e de criação de animais.

A posse livre de terra esteve presente na sociedade brasileira desde o período colonial e foi praticada concomitantemente à forma de apropriação territorial baseada em decretos, leis e regulamentos impostos pela Coroa portuguesa. Assim, desde o início da colonização, subsistiram o sistema sesmarial e o apossamento livre, também denominado de posse pura e simples. Todavia, entre 1822 e 1850, depois que D. Pedro instituiu a provisão de 14 de março de 1822, permitindo a permanência dos posseiros nas terras cultivadas e a resolução de 17 de 
julho do mesmo ano, interrompendo a ocupação de terras por meio da doação de sesmarias, a prática do apossamento livre foi intensificada. ${ }^{57}$

\title{
Latifundiário-sesmeiros da fronteira oeste
}

Em terras abundantes de água, barreiros e pastos nativos, os posseiros precisavam somente garantir o poder sobre as extensas terras ocupadas. O gado vacum, criado à solta nesse território agraciado por belezas e recursos naturais apropriados, demandava manejo esporádico e, portanto, proporcionava uma vida mais tranquila aos ocupantes de terras da região. De acordo com Alfredo d'Escragnolle Taunay, na obra "Scenas de viagem: exploração entre os rios Taquary e Aquidauana no districto de Miranda", de 1868, poucas atividades eram exigidas dos criadores mato-grossenses: marcação, costeio e negociação dos vacuns. Sobre o proprietário rural dos pantanais da parte sul da província de Mato Grosso, relatou:

\begin{abstract}
A vida do fazendeiro é marcar, em certas épocas do anno, os bezerros, costear o gado, de quando em quando, e negociar com elle. Sua fazenda é uma área de terreno indeterminada, muitas vezes com 5,10, 20 legoas de extensão, tendo, em certo ponto, um rancho, coberto quase sempre de palha, raras vezes de telha, que serve de vivenda ao dono d'essas propriedades, onde caberião, à larga, dez a doze grãoducados ou principados alemães. ${ }^{58}$
\end{abstract}

Os fazendeiros, assentados em imensas glebas com suas famílias, cativos e camaradas, viveram envoltos pela simplicidade, em moradias rústicas, com mobília e objetos restritos às principais atividades cotidianas. Utensílios mais sofisticados como pratos, salvas, talheres, xícaras e demais objetos de louça eram raros nas casas rurais. Itens luxuosos de mobília também não faziam parte dos interiores das moradias pantaneiras. O certo é que a vida em terras inóspitas obrigou os indivíduos à singeleza, à adaptação e aos costumes nativos. Assim, na ausência das camas, dos preguiceiros e dos guarda-roupas, havia os bancos de madeiras, os baús e as redes. Na falta de panelas de ferro e utilitários de porcelana, objetos feitos de barro pelos nativos da região eram úteis para preparar e servir os alimentos à mesa. É preciso mencionar, no entanto, que alguns proprietários rurais, embora incrustados em território pantaneiro, usufruíram de alguns objetos requintados. Devido ao espaço nesse trabalho, serão referenciados somente alguns fazendeiros.

O proprietário de terras da região Francisco Xavier Ribeiro, embora dispusesse de uma sesmaria de campos de criar, chamada Coqueiros, com extensão de "sete léguas mais ou menos" [42.000 m aproximadamente] e uma fazenda denominada Bonito, de "cinquenta léguas mais ou menos de campo" [33.000 hectares aproximadamente], parece ter vivido de 
forma singela junto aos seus seis filhos e à sua esposa, Alexandrina de Souza Ribeiro. Ao falecer, em 1877, além das posses citadas, deixou por herança um terreno com a extensão de "14 braças e meia [31,9 m] na rua do Carmo esquina da igreja Matriz entre Mamede João Cordeiro", uma casa com "dois lanços de frente, corredor e varanda na rua do Carmo da vila de Miranda entre Joaquim de Souza Mariano e Evaristo José Gomes” e, finalmente, uma casa não concluída em "Nioaque no largo do quartel". 59

Havia, na sesmaria Coqueiros, uma casa coberta de capim, seis currais novos e um grande mandiocal. $\mathrm{Na}$ fazenda Bonito,existiam as seguintes benfeitorias: casa coberta de capim, cinco lances grandes de curral com monjolo, rego de água abundante e um engenho novo de moer cana.

Poucos objetos utilizados no cotidiano rural foram inventariados. Podemos citar um alambique novo de cobre, dois carros em mau estado, dois tachos de cobre usados, três selas vaqueiras e três freios. A documentação mostra que os bens mais valiosos da família eram as terras e os animais. Os animais descritos renderam aos herdeiros 19:720\$000 réis e os bens de raiz, o valor de 11:370\$000 réis. O inventariado mantinha, na fazenda Coqueiros, 600 reses alçadas e 20 éguas baguais e nas terras Bonito 300 reses mansas, 20 cavalos de serviço e 12 éguas baguais. No total, a família herdou 952 animais, espalhados pelos campos de Bonito e Coqueiros. $^{60}$

De maneira diferente viveramHenrique Augusto Ferreira de Andrade e Gertrude Nunes Ferreira. Típicos proprietários absenteístas, possuíam uma casa e um lote de terras na vila de Miranda e cinco propriedades. Nem por isso desfrutaram de maior requinte.

$\mathrm{Na}$ execução do inventário de Henrique Augusto Ferreira de Andrade, em 1873, encontramos em bens de raiz na vila de Miranda: uma casa com quintal, localizada na rua $1^{\circ}$ de Março, com "25 braças de frente e 35 de fundo" [4.235 $\mathrm{m}^{2}$ ] e um lote de terra, "confinando ao Sul com a nova igreja Matriz. Também uma fazenda chamada Correntes, "na margem esquerda rio Aquidauana com seis léguas de frente e sete de fundo [182.952 hectares] confinando ao sul a Serra denominado João Nunes ao Poente com Canuto e Nascente com a Cachoeira Grande"; um terreno contíguo à fazenda Correntes, com "três léguas de frente e uma de fundo" [13.068 hectares]; uma fazendinha denominada Catêpa, margem direita do rio Miranda; a sesmaria Lagiado, em cima da serra; e, finalmente, a sesmaria Agachi. Nas posses Catêpa e Lagiado, eram mantidasa lavoura e a criação de gado. ${ }^{61}$

Além das propriedades rurais arroladas, constavam 812 animais em posse da família:800 cabeças de gado vacum e 12 cavalares. A relação dos bens móveis era diminuta, 
constituindo-se somente de um carro ferrado com seus ginetes, no valor de $800 \$ 000$ réis. É possível que os limitados trastes usados no dia a dia pouco valessem para entrarem no rol da partilha.

O fazendeiro em referência mantinha, sob seu poder, alguns escravizados: Félix Ferreira, Gaudencio, Hylario Ferreira e Reginaldo Ferreira. Verificamos que, na relação dos cativos matriculados por Deocleciano Augusto Ferreira, a pedido da mãe Gertrude Nunes Ferreira, estava o registro de que os cativos residiam na vila, com especialidades ligadas ao universo urbano. ${ }^{62}$ É possível que os escravizados Félix, pajem, Gaudencio, cozinheiro e Hylario, também pajem, trabalhassem no interior da moradia do casal, localizada na vila de Miranda. Com relação ao cativo Reginaldo, com especialidade de ourives, provavelmente executava o serviço de ganho.

Na fazenda de Miguel João de Castro, denominada Boa Vista e localizada à margem direita do rio Aquidauana, a moradia possuía cobertura de telha e media 60 palmos de frente [13,2 m] com 40 de fundos [8,8 m]. A família era servida por escravizados. A cativa Mariana, 22, parda e natural de Santana de Paranaíba, descrita com a profissão de cozinheira, provavelmente realizava todas as atividades da casa. Ricarda Pires, 18, cabra, com a especialidade de pajem, presumivelmente auxiliava nos trabalhos cotidianos. ${ }^{63}$

No interior da moradia, poucos objetos eram utilizados. No entanto, vale enfatizar a qualidade e a raridade do mobiliário encontrado, quando comparado aos objetos de uso das demais moradias rurais da região de Miranda. Na casa de Miguel João, havia seis cadeiras de palhinha, seis mesas encouradas, duas mesas de jantar pequenas, um armário, um baú grande encourado, uma canastra coberta de sola, uma mesa de jantar, um paliteiro de prata, um par de castiçal de prata, um relógio de mesa com redoma de vidro e uma salva de prata. Objetos de prata, como os citados, raras vezes eram vistos no universo rural oitocentista da região.

Quando executado o inventário de bens, em 1882, devido ao falecimento de Maria Pires, esposa de Miguel João, não foram arrolados animais de criação. A família devia sobreviver do cultivo de pequenas roças de cana-de-açúcar, feijão, mandioca, milho, entre outros cereais utilizados na alimentação cotidiana. Consta que havia na propriedade um engenho de madeira para moer cana e os objetos necessários para a preparação do melado e do açúcar, como tachos de cobre. Havia ainda uma prancha pequena ${ }^{64}$, usada para o deslocamento até a vila de Miranda.

Em direção à fronteira oeste da província mato-grossense, mais exatamente no território de Corumbá, existiram outros proprietários de terras dedicados à criação de animais 
e ao plantio de pequenas roças. A exemplo, o proprietário rural Joaquim José Gomes da Silva $^{65}$, o barão de Vila Maria, título concedido em 21 de junho de 1862 pelo Governo Imperial.

Alfredo d'Escragnolle Taunay, ao discorrer sobre os proprietários de terras da região, sublinhou o nome do barão de Vila Maria, por apresentar, à época, e em comparação com os demais posseiros do território da parte sul da província, "espírito de atividade e gosto pelo trabalho, pouco communs na província". ${ }^{66}$ Aliás, o citado fazendeiro e a sua fazenda Piraputangas foram referências constantesnas memórias dos viajantes estrangeiros do final do oitocentos, muito provavelmente por encontrarem, no local,o pouso e a alimentação necessários nos deslocamentos pela região. A extensão, a beleza natural, a existência de construções regulares, o engenho e as roças também constituíam elementos relevantes para a descrição dos viajantes, acostumados à repetida singeleza da arquitetura rural da região sul de Mato Grosso.

\section{Considerações finais}

Apesar de significativos avanços iniciados pelos pesquisadores citados sobre a questão agrária enão obstante o grande impulso dado pela instalação dos Programas de Pós-Graduação no Brasil, com o objetivo de pensar as relações de poder e de propriedade no Brasil oitocentista e da multiplicação de trabalhos acadêmicos ancorados em pesquisas empíricas, como os desenvolvidos por Hebe Maria Mattos de Castro, em 1985, Márcia Maria Menendes Motta, em 2008, Manoela Pedroza, em 2011, entre outros ${ }^{69}$, boa parte da comunidade historiadora pouco conhece sobre o universo rural do passado ou sobre o papel dos movimentos sociais rurais do século 19.

Nessa trilha aberta entre os anos 1970-1990, seguimos palmilhando, ainda que tardiamente, no contexto regional, com o propósito de fazer avançarem os estudos históricos sobre as estratégias de apossamento, dilatação das propriedades, relações de trabalho, assim como os conflitos gerados em torno da posse e da manutenção das terras no espaço dos campos sulinos de Mato Grosso. Emergiu desses estudos o conhecimento sobre parte das paisagens rurais sul-mato-grossenses, marcadas pela conformação de propriedades, com diferentes extensões, pequenas, médias e grandes, e sobre as várias categorias sociais, como agregados, lavradores, camaradas, vaqueiros, entre outros, que ali se movimentaram, delineando uma vida material singular. 
A despeito do predomínio do mundo rural na história brasileira; apesar do reconhecimento geral acerca da importância de estudos sobre a ruralidade, conforme procuramos demonstrar; apesar da permanência de uma visão tradicional que nega o caráter conflituoso de ocupação de terras no país; não obstante a persistência, nas abordagens conservadoras,da imagem patriarcal do grande proprietário e da desqualificação do trabalhador livre pobre, este por vezes oculto desse universo, tradicionalmente pensado como o espaço do binômio escravizador/escravizado; infelizmente, os estudos sobre o universo rural de Mato Grosso ainda abordam tais questões apenas tangencialmente.

Passados quase 40 anos do desenvolvimento do Programa de Pesquisa sobre a História da Agricultura Brasileira (iniciado nos anos de 1976-1977), liderado por Linhares, com o propósito de fazer avançarem os estudos sobre a ruralidade brasileira; vencidos os 35 anos do surgimento dos primeiros trabalhos acadêmicos sobre as relações de trabalho em Mato Grosso; passados 20 anos do momento em que João Antônio Botelho Lucídio, orientado por Linhares, se debruçou sobre a problemática do universo rural do planalto sul de Mato Grosso;transcorridos cinco anos da execução do Projeto “A produção pastoril no Piauí, no Mato Grosso do sul e no Rio Grande do Sul”, em 2007; ainda é demasiadamente grande a lacuna historiográfica existente a respeito da problemática terra/trabalho no meio acadêmico. No entanto, isso não significa ausência de interesse ou de fontes históricas disponíveis a respeito. Ao contrário, faltam-nos, na verdade, projetos com fomento para garantir a dedicação mais efetiva e a mobilização de pesquisadores junto aos arquivos locais, regionais e nacionais.

\section{Notas}

${ }^{1}$ FRANCO, Maria Sylvia de Carvalho. Homens livres na ordem escravocrata. 4. ed. São Paulo: Editora Unesp, 1997; MARTINS, José de Souza. O cativeiro da terra. 2. ed. São Paulo: Ciências Humanas, 1979; LINHARES, Maria Yedda; SILVA, Francisco Carlos Teixeira da. História da agricultura brasileira: combates e controvérsias. São Paulo: Brasiliense, 1981.

${ }^{2}$ FRAGOSO, João Luiz Ribeiro. Sistemas Agrários em Paraíba do Sul. Um estudo das relações não capitalistas de produção. 1974. Dissertação (Mestrado em História Social), UFRJ, Rio de Janeiro.

${ }^{3}$ FARIA, Sheila Siqueira de Castro. Terra e Trabalho em Campos dos Goytacazes, 1850-1920. 1986. Dissertação (Mestrado em História), UFF, Rio de Janeiro; GRANER, Maria Paula. A Estrutura Fundiária do Município de Araruama, 1850-1920. 1986. Dissertação (Mestrado em História). UFF, Niterói; CASTRO, Hebe Maria da Costa Mattos Gomes de. A Margem da História: homens livres, pobres e pequena produção na crise do trabalho escravo - Capivary (Silva Jardim), 1850-1920. 1985. Dissertação (Mestrado em História), UFF, Rio de Janeiro

${ }^{4}$ VINHAES, Eliana. Cantagalo - estudo das formas de organização e acumulação de terra e riqueza. 1992. Tese (Doutorado em História), UFRJ. Rio de Janeiro; LUCÍDIO, João Antonio Botelho.Nos Confins do Império, um deserto de homens povoado por bois. 1993. Dissertação (Mestrado em História), UFF, Rio de Janeiro; MOTTA, Márcia Maria Menendes. Pelas 'Bandas d'Além'- fronteira fechada e arrendatários escravistas numa região policultora, 1808-1888. 1989. Dissertação (Mestrado em História), UFF, Rio de Janeiro; FARIA, Sheila 
Siqueira de Castro. Terra e Trabalho em Campos dos Goytacazes, 1850-1920. 1986. Dissertação (Mestrado em História), UFF, Rio de Janeiro.

${ }^{5}$ BARROS, Edval de Souza. Proprietários rurais e estado português em meio ao avanço da fronteira agrária escravista: a Capitania do Rio de Janeiro (1763-1808). 1997. Dissertação (Mestrado em História), UFF, Rio de Janeiro; OSÓRIO, Helen. Apropriação da terra no Rio Grande de São Pedro e a formação do espaço platino. 1990. Dissertação (Mestrado), UFRGS; RUIZ, Ricardo Muniz de. Sistema agrário, demografia da escravidão e família escrava em Itaguay-séc. XIX-1830-1872. 1997. Dissertação (Mestrado em História), UFF; Mônica Ribeiro de Oliveira. Negócios de Família: mercado, terra e poder na formação da cafeicultura mineira (17891870). 1999. (Doutorado em História), UFF.

${ }^{6}$ CHRISTILLINO, Cristiano Luís. Litígios ao sul do Império: a Lei de Terras e a consolidação política da Coroa (1850-1880). 2010. Tese (Doutorado em História), UFF, Niterói; GARCIA, Graciela Bonassa. Terra, Trabalho e Propriedade: A estrutura agrária da Campanha rio-grandense nas décadas finais do período imperial (18701890). 2010. Tese (Doutorado em História), UFF, Niterói.

${ }^{7}$ LUCÍDIO, João Antonio Botelho.Nos Confins do Império, um deserto de homens povoado por bois. 1993. Dissertação (Mestrado em História), UFF, Rio de Janeiro. p. 4.

${ }^{8}$ ALEIXO, Lúcia Helena Gaeta. Mato Grosso: trabalho escravo e trabalho livre (1850-1888). Brasília: Ministério da Fazenda, Departamento de administração, Divisão de Documentação, 1984.

${ }^{9}$ VOLPATO, Luiza Rios Ricci. Cativos do sertão: vida cotidiana e escravidão em Cuiabá em 1850-1888. São Paulo: Editora Marco Zero; Cuiabá, MT: EdUFMT, 1993. p. 20.

${ }^{10}$ MORENO, Gislaene. Terra e Poder em Mato Grosso. Política e mecanismos de burla-1892-1992. Cuiabá-MT, Entrelinhas-EdUFMT, 2007.

${ }^{11}$ MAESTRI, Mário; Maria do Carmo Brazil (Orgs.). Peões, vaqueiros \& cativos campeiros. Estudos sobre a economia pastoril no Brasil.(TOMO I), 2009; MAESTRI, Mário; Solimar Oliveira Lima (Orgs.). Peões, vaqueiros \& cativos campeiros. Estudos sobre a economia pastoril no Brasil.(TOMO II), 2010. MAESTRI, Mário; Júlio Quevedo dos Santos; Paulo Esselin (Orgs.). Peões, vaqueiros \& cativos campeiros. Estudos sobre a economia pastoril no Brasil. (TOMO III), 2010.

${ }^{12}$ Revista História Debates e Tendências, v.7, n.2, jul./dez., $2007 . \quad$ Disponível em: http://www.upf.br/seer/index.php/rhdt Acesso em: 10 de março de 2016.

${ }^{13}$ BRAZIL, Maria do Carmo. Sobre os campos de Vacaria do sul de Mato Grosso: considerações de terra e escravidão (1830-1889). IN: MAESTRI, Mário e BRAZIL, Maria do Carmo (Orgs.). Peões, vaqueiros \& cativos campeiros: estudos sobre a economia pastoril no Brasil. Passo Fundo: EdUPF, 2009, p. 219-250; CANCIAN, Elaine. Propriedades pastoris e escravidão no Pantanal de Miranda (sec. 19). IN: MAESTRI, Mário e BRAZIL, Maria do Carmo (Orgs.). Peões, vaqueiros \& cativos campeiros: estudos sobre a economia pastoril no Brasil. Passo Fundo: EdUPF, 2009. p.251-289; ALMEIDA, Elaine Aparecida Cancian de. Nos confins do sertão de Miranda: Ocupação da terra, desenvolvimento econômico e relações de trabalho (1830-1892).2014. (Tese) Doutorado em História- Dourados, MS: UFGD, 557 f.; CAMARGO, I. C., O sertão de Santana de Paranaíba: um perfil da sociedade pastoril-escravista no sul do antigo Mato Grosso (1830 - 1888); SILVA, Adilson Rodrigues. "Sertão" de Coxim: Apossamento de Terras, Conquistas e Relações de Trabalho (1830-1898). Dourados, MS : UFGD, 2013.

${ }^{14}$ AYALA, S. Cardoso e SIMON, F. O: Albumgraphico do Estado de Matto Grosso. Corumbá, Hamburgo, 1914, p. 419; CAMPESTRINI, H. Sant'Ana de Paranaíba. De 1700 a 2002. 3.ed. Campo Grande, MS: IHGMS, 1997, p. $36-41$.

${ }^{15}$ CAMARGO, Isabel Camilo de. O sertão de Paranaíba: Um perfil da sociedade pastoril - escravista no sul do antigo Mato Grosso (1830-1888). 2012. Dissertação (Mestrado em História), UFGD, Dourados.

${ }^{16}$ ELLIOTT, João Henrique. Itinerário das viagens exploradoras empreendidas pelo Sr. Barão de Antonina. Revista doInstituto Histórico e Geográfico Brasileiro. 2. ed. Rio de Janeiro, 1870, p.153-177.

${ }^{17}$ A bandeira de Joaquim Francisco Lopes - 1829. In:Boletim do Departamento do Arquivo do Estado de São Paulo, vol. III. São Paulo, Tip. Do Globo, 1943. Disponível em: http://www.dominiopublico.gov.br/download/texto/ub00038a.pdf. Acessado: 26 de julho de 2009.

${ }^{18}$ SABOYA, Vilma Eliza Trindade de. A Lei de Terras (1850) e a política imperial - seus reflexos naProvíncia de Mato Grosso. Revista Brasileira de História. Historiografia propostas e práticas. São Paulo: Contexto, 1995. v. 15, n.30, p. 130-132.

${ }^{19}$ WISSENBACH, Maria Cristina. Cortez. Desbravamento e catequese na constituição da nacionalidade brasileira: as expedições do barão de Antonina no Brasil Meridional. Revista Brasileira de História, São Paulo, v. 15 , n. 30, p. 137-155, 1995.

${ }^{20}$ ALMEIDA, Mario Monteiro de. Episódios Históricos da Formação Geográfica do Brasil. Fixação das raias com o Uruguai e o Paraguai. Rio de Janeiro: Irmãos Pongetti, 1951.p.240. 
${ }^{21}$ SILVA, Ligia Osório. Terras devolutas e Latifúndio: efeitos da lei de 1850. 2. ed. Campinas/SP: EdUnicamp, 2008; MOTTA, Marcia Maria Menendes. Nas fronteiras do poder: conflito e direito à terra no Brasil do século XIX. 2. ed. Rev.eampl. Niterói: EDUFF, 2008.

${ }^{22}$ CERQUEIRA, E. (Org.). Obras científicas, políticas e sociais de José Bonifácio de Andrada e Silva, p. 265.

${ }^{23}$ LIMA, Rui Cirne. Escravidão em Mato Grosso: um balanço historiográfico. In: XXV Simpósio Nacional de História-História e Ética, 2009, Fortaleza. Anais do XXV Simpósio Nacional de História -História e Ética. Fortaleza: Universidade Federal do Ceará/ANPUH-Nacional, 2009. v. 1. p. 1-18. p. 58.

${ }^{24}$ CORRÊA FILHO, Virgílio. A propósito dos novos territórios - comentários despretensiosos. Rio de Janeiro: Jornal do Comércio, p. 8.

${ }^{25}$ PESSOA, Angelo Emílio da Silva Pessoa. As ruínas da tradição: a casa da torre de Garcia D'ávila. Família e propriedade no nordeste coloquial. 2003. (Tese de Doutorado em História Social, FFLCH/USP).p. 34.

${ }^{26}$ SANTOS FILHO, Lycurgo. Uma Comunidade Rural no BrasilAntigo (aspectos da Vida Patriarcal no Sertão da Bahia nos Séculos XVIII e XIX), São Paulo: Nacional, 1956. p. 55.

${ }^{27}$ CORRÊA FILHO, Virgílio Questões de terras. Secção de Obras d'O Estado de São Paulo, 1923, p.3.

${ }^{28}$ Sobre o tema consultar PORTO. José da Costa. O Sistema Sesmarial no Brasil. 2 ed. Brasília. Ed. UnB, 1979.

${ }^{29}$ ALMEIDA, Mário Monteiro de. Episódios históricos da formação geográfica do Brasil: fixação das raias com o Uruguai e o Paraguai. Rio de Janeiro: Pongetti, 1951.

${ }^{30}$ Idem, p.240.

${ }^{31}$ Idem.

${ }^{32}$ BRAZIL, Maria do Carmo. Rio Paraguai. O 'mar interno' brasileiro. Campo Grande-MS: EdUFMS,2014. p.110-215.

${ }^{33}$ PENTEADO, Yara (Org.). 'Como se de ventre livre nascido fosse...'.CampoGrande-MS: SEJT-SEEB/MSMinistério da Cultura-Fundação Palmares/DF, 1993.

${ }^{34}$ Idem.

${ }^{35}$ BRAZIL, Maria do Carmo. Sobre os campos de Vacaria do sul de Mato Grosso: considerações de terra e escravidão (1830-1889). IN: MAESTRI, Mário e BRAZIL, Maria do Carmo (Orgs.). Peões, vaqueiros \& cativos campeiros: estudos sobre a economia pastoril no Brasil. Passo Fundo: Ed. Universidade de Passo Fundo, 2009, p. 240.

${ }^{36}$ FLEURY, Justiniano Augusto de Salles [1925]. O descobrimento do sertão e fundação da povoação de Sant'Anna do Paranahyba: artigos extrahidos do Republicano de Cuyabá, de 12 de dezembro de 1895 e números subseqüentes. Revista do Instituto Histórico de Mato Grosso, Cuiabá, anos 6/7, Tomo 13, 1925, p. 30-46.

${ }^{37}$ Ibid., p. 243.

${ }^{38}$ FLEURY, Justiniano Augusto de Salles. O Descobrimento do Sertão e fundação de Santana do Paranaíba. Artigo extraído do Republicano de Cuiabá, de 12 de dezembro de 1895. (Apontamentos). Revista do Instituto Histórico de Mato Grosso, anos 6/7, Tomo 13.

${ }^{39}$ Idem.

${ }^{40}$ Idem.

${ }^{41}$ ORTIZ, Helen Scorsatto. O banquete dos ausentes: A Lei de Terras e a formação do latifúndio no norte do Rio Grande do Sul (Soledade - 1850-1889). 2006. Dissertação (Mestrado em História), UPF, Passo Fundo. p. 9-25.

${ }^{42}$ Ibidem.

${ }^{43}$ BRAZIL, Maria do Carmo; CANCIAN, Elaine. A Rusga Cuiabana e a ocupação do sul de Mato Grosso: apontamentos de pesquisa. IN: SENA, Ernesto; PERARO, Maria Adenir. (Orgs.) Rusga. Uma rebelião no sertão. Mato Grosso no período Regencial. Cuiabá: EdUFMT, 2014.

${ }^{44}$ ALMEIDA, Mário Monteiro de. Episódios Históricos da Formação Geográfica do Brasil. Fixação das raias com o Uruguai e o Paraguai, Rio de Janeiro: Irmãos Pongetti, 1951, p. 225.

${ }^{45}$ ALMEIDA, Mário Monteiro de. Episódios Históricos da Formação Geográfica do Brasil. Fixação das raias com o Uruguai e o Paraguai, Rio de Janeiro: Irmãos Pongetti, 1951. p. 227 e 233. O leitor também poderá consultar tabela relativa aos posseiros e as denominações das suas posses estabelecidas na parte sul da província de Mato Grosso nos anos de 1833 a 1847. A mesma pode ser consultada em: ALMEIDA, Elaine Aparecida Cancian de. Nos confins do sertão de Miranda: Ocupação da terra, desenvolvimento econômico e relações de trabalho (1830-1892), 2014. Tese (Doutorado em História), UFGD, Dourados-MS. p. 209-210.

${ }^{46}$ ALMEIDA, Elaine Aparecida Cancian de. Nos confins do sertão de Miranda: Ocupação da terra, desenvolvimento econômico e relações de trabalho (1830-1892), 2014. Tese (Doutorado em História). UFGD. p.365.

${ }^{47}$ ALMEIDA, Mário Monteiro de. Episódios Históricos da Formação Geográfica do Brasil. Fixação das Raias com o Uruguai e o Paraguai. Rio de Janeiro: Irmãos Pongetti, 1951. p. 230.

${ }^{48}$ D’ALINCOURT, Luiz.Memória sobre a viagem do porto de Santos à cidade de Cuiabá. Belo Horizonte-São Paulo: Itatiaia-EdUSP, 1975.

${ }^{49}$ ALMEIDA, Mário Monteiro de. Op. Cit., p. 230. 


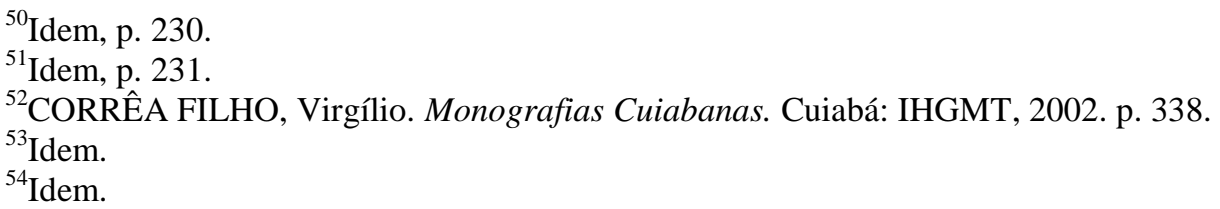

${ }^{55}$ ESSELIN, Paulo Marcos. A pecuária bovina e o processo de ocupação do Pantanal Sul-mato-grossense. In: MAESTRI, Mário; BRAZIL, Maria do Carmo, (Orgs.). Peões, vaqueiros \& cativos campeiros. Estudos sobre a economia pastoril no Brasil, p. 317-318.

${ }^{56}$ CAMPESTRINI, Hildebrando. (Atual. e Introd.). As derrotas de Joaquim Francisco Lopes. Instituto Histórico e Geográfico de Mato Grosso do Sul, 2007. Disponível em: http://www.ihgms.com.br/biblioteca/biblioteca.asp. Acesso em: 30 de janeiro de 2011.

p. 15-17.

${ }^{57}$ Reflexões aprofundadas sobre o sistema sesmarial e o apossamento livre de terras podem ser encontradas em: MOTTA, Márcia Maria Menendes. Sesmarias e o mito da primeira ocupação. RevistaJustiça \& História,Rio Grande do Sul,v. 4, n.7, p. 01-17, 2004. Disponível em: http://www.tjrs.jus.br/site/poder_judiciario/historia/memorial_do_poder_judiciario/memorial_judiciario_gaucho/ revista_justica_e_historia/. Acesso em: fevereiro de 2013.; ORTIZ, Helen. S., A apropriação da terra no Brasil: da lei de sesmarias à lei de terras (1532-1850). In: MAESTRI, M.; LIMA, Solimar O., Peões, vaqueiros \& cativos campeiros. Estudos sobre a economia pastoril no Brasil, 2010; SILVA, Ligia Osorio. Terras devolutas e latifúndio. 2. ed. Campinas-SP: EdUnicamp, 2008.

${ }^{58}$ TAUNAY, Alfredo d' Escragnolle. Scenas de Viagem. Exploração entre os rios Taquary e Aquidauana no distrito de Miranda. Memória descriptiva. Rio de Janeiro: Typographia Americana, 1868.p. 60-61.

${ }^{59}$ Inventário de Francisco Xavier Ribeiro, 1877. Caixa n $156-07$. Arquivo e Memorial do Tribunal de Justiça de Campo Grande/MS.

${ }^{60}$ Idem.

${ }^{61}$ Inventário de Henrique Augusto Ferreira de Andrade, 1873. Caixa nº 156-01. Arquivo e Memorial do Tribunal de Justiça de Campo Grande/MS.

${ }^{62}$ Os cativos foram matriculados no Livro de matrícula especial dos escravos da vila de Miranda. Folha 5 verso. Ver: Inventário de Henrique Augusto Ferreira de Andrade, 1873. Caixa no 156-01, p. 10-11. Arquivo e Memorial do Tribunal de Justiça de Campo Grande/MS.

${ }^{63}$ Inventário de Maria Pires de Veiga, 1882. Caixa 158/01. Arquivo e Memorial do Arquivo e Memorial do Tribunal de Justiça de Campo Grande/MS.

${ }^{64} \mathrm{~A}$ prancha, impulsionada à vara era um meio de transporte de carga característico da região, muito usado em alguns rios da bacia do Paraguai.

${ }^{65}$ Parte da trajetória de vida de Joaquim José Gomes da Silva pode ser encontrada em: CANCIAN, Elaine; BRASIL, Maria do Carmo. O barão de vila Maria. Poder, história agrária e memória em Mato Grosso. IN: BORGES, Fernando Tadeu de Miranda; PERARO, Maria Adenir; COSTA, Viviane Gonçalves. (Orgs.) Trajetórias de Vidas na História. Cuiabá: EdUFMT, Carlini e Caniato Editorial, 2008.p.93-116.

${ }^{66}$ TAUNAY, Alfredo d'Escragnolle. Scenas de viagem: exploração entre os rios Taquary e Aquidauana no districto de Miranda, 1868, p. 61.

${ }^{67}$ CASTRO, Hebe Maria Mattos de. Ao Sul da História. Lavradores pobres na crise do trabalho escravo. Rio de Janeiro: EdFGV, Faperj, 2009; MOTTA, Márcia Maria Menendes. Nas fronteiras do poder. Conflito e direito à terra no Brasil do século XIX. 2. ed. rev. ampl. Niterói: EdUFF, 2008; PEDROZA, Manoela. Engenhocas da Moral: redes de parentela, transmissão de terras e direitos de propriedade na freguesia de Campo Grande (Rio de Janeiro, século XIX). Rio de Janeiro: Arquivo Nacional, 2011.

\section{Referências Bibliográficas}

ALEIXO, Lúcia Helena Gaeta. Mato Grosso: trabalho escravo e trabalho livre (1850-1888). Brasília: Ministério da Fazenda, Departamento de administração, Divisão de Documentação, 1984.

ALMEIDA, Elaine Aparecida Cancian de. Nos confins do sertão de Miranda: Ocupação da terra, desenvolvimento econômico e relações de trabalho (1830-1892). 2014. (Tese) (Doutorado em História), UFGD, Dourados, MS. 
ALMEIDA, Mario Monteiro de. Episódios Históricos da Formação Geográfica do Brasil. Fixação das raias com o Uruguai e o Paraguai. Rio de Janeiro: Irmãos Pongetti, 1951.

AYALA, S. Cardoso e SIMON, F. O: Albumgraphico do Estado de Matto Grosso. Corumbá, Hamburgo, 1914.

BARROS, Edval de Souza. Proprietários rurais e estado português em meio ao avanço da fronteira agrária escravista: a Capitania do Rio de Janeiro (1763-1808). 1997. Dissertação (Mestrado em História), UFF, Rio de Janeiro.

Boletim do Departamento do Arquivo do Estado de São Paulo, vol. III. São Paulo, Tip. Do Globo, $1943 . \quad$ Disponível em: http://www.dominiopublico.gov.br/download/texto/ub00038a.pdf. Acesso: 26 de julho de 2009.

BRAZIL, Maria do Carmo. Escravidão em Mato Grosso: um balanço historiográfico In: XXV Simpósio Nacional de História-História e Ética, 2009, Fortaleza. Anais do XXV Simpósio Nacional de História-História e Ética. Fortaleza: Universidade Federal do Ceará/ANPUHNacional, 2009.

BRAZIL, Maria do Carmo. Rio Paraguai. O 'mar interno' brasileiro. Campo GrandeMS:EdUFMS,2014.

BRAZIL, Maria do Carmo. Sobre os campos de Vacaria do sul de Mato Grosso: considerações de terra e escravidão (1830-1889). IN: MAESTRI, Mário e BRAZIL, Maria do Carmo (Orgs.). Peões, vaqueiros \& cativos campeiros: estudos sobre a economia pastoril no Brasil. Passo Fundo: EdUPF, 2009.

BRAZIL, Maria do Carmo; CANCIAN, Elaine. A Rusga Cuiabana e a ocupação do sul de Mato Grosso: apontamentos de pesquisa. IN: SENA, Ernesto; PERARO, Maria Adenir. (Orgs.).Rusga. Uma rebelião no sertão. Mato Grosso no período Regencial. Cuiabá: EdUFMT, 2014.

CAMARGO, Isabel Camilo de. O sertão de Paranaíba: Um perfil da sociedade pastoril escravista no sul do antigo Mato Grosso (1830-1888). 2012. Dissertação (Mestrado em História), UFGD, Dourados.

CAMPESTRINI, Hildebrando. Sant'Ana de Paranaíba. De 1700 a 2002. 3.ed. Campo Grande, MS: IHGMS, 1997.

CAMPESTRINI, Hildebrando. (Atual. e Introd.). As derrotas de Joaquim Francisco Lopes. Instituto Histórico e Geográfico de Mato Grosso do Sul, 2007. Disponível em: http://www.ihgms.com.br/biblioteca/biblioteca.asp. Acesso em: 30 de janeiro de 2011.

CANCIAN, Elaine. Propriedades pastoris e escravidão no Pantanal de Miranda (sec. 19). IN: MAESTRI, Mário e BRAZIL, Maria do Carmo (Orgs.). Peões, vaqueiros \& cativos campeiros: estudos sobre a economia pastoril no Brasil. Passo Fundo: EdUPF, 2009.

CANCIAN, Elaine; BRASIL, Maria do Carmo. O barão de vila Maria. Poder, história agrária e memória em Mato Grosso. IN: BORGES, Fernando Tadeu de Miranda; PERARO, Maria Adenir; COSTA, Viviane Gonçalves. (Orgs.) Trajetórias de Vidas na História. Cuiabá: EdUFMT, Carlini e Caniato Editorial, 2008.

CASTRO, Hebe Maria Mattos de. Ao Sul da História. Lavradores pobres na crise do trabalho escravo. Rio de Janeiro: EdFGV, Faperj, 2009.

CERQUEIRA, Edgard de. (Org.). Obras científicas, políticas e sociais de José Bonifácio de Andrada e Silva. São Paulo: Revista dos Tribunais, 1963.

CHRISTILLINO, Cristiano Luís. Litígios ao sul do Império: a Lei de Terras e a consolidação política da Coroa (1850-1880). 2010. Tese (Doutorado em História), UFF, Niterói.

CORRÊA FILHO, Virgílio Questões de terras. Secção de Obras d'O Estado de São Paulo, 1923. 
CORRÊA FILHO, Virgilio. A propósito dos novos territórios - comentários despretensiosos. Rio de Janeiro: Jornal do Comércio, 1944.

CORRÊA FILHO, Virgílio. Monografias Cuiabanas. Cuiabá: IHGMT, 2002.

ELLIOTT, João Henrique. Itinerário das viagens exploradoras empreendidas pelo Sr. Barão de Antonina. Revista doInstituto Histórico e Geográfico Brasileiro. 2. ed.Rio de Janeiro, 1870 .

FARIA, Sheila Siqueira de Castro. Terra e Trabalho em Campos dos Goytacazes, 1850-1920. 1986. Dissertação (Mestrado em História), UFF, Rio de Janeiro.

FLEURY, Justiniano Augusto de Salles [1925]. O descobrimento do sertão e fundação da povoação de Sant'Anna do Paranahyba: artigos extrahidos do Republicano de Cuyabá, de 12 de dezembro de 1895 e números subseqüentes. Revista do Instituto Histórico de Mato Grosso, Cuiabá, anos 6/7, Tomo 13, 1925.

FRAGOSO, João Luiz Ribeiro. Sistemas Agrários em Paraíba do Sul. Um estudo das relações não capitalistas de produção. 1974. Dissertação (Mestrado em História Social), UFRJ, Rio de Janeiro.

FRANCO, Maria Sylvia de Carvalho. Homens livres na ordem escravocrata. 4. ed. São Paulo: Editora Unesp, 1997.

GARCIA, Graciela Bonassa. Terra, Trabalho e Propriedade: A estrutura agrária da Campanha rio-grandense nas décadas finais do período imperial (1870-1890). 2010. Tese (Doutorado em História), UFF, Niterói.

GRANER, Maria Paula. A Estrutura Fundiária do Município de Araruama, 1850-1920. 1986. Dissertação (Mestrado em História). UFF, Niterói.

LIMA, Rui Cirne. Escravidão em Mato Grosso: um balanço historiográfico. In: XXV Simpósio Nacional de História-História e Ética, 2009, Fortaleza. Anais do XXV Simpósio Nacional de História -História e Ética. Fortaleza: Universidade Federal do Ceará/ANPUHNacional, 2009.

LINHARES, Maria Yedda; SILVA, Francisco Carlos Teixeira da. História da agricultura brasileira: combates e controvérsias. São Paulo: Brasiliense, 1981.

LUCÍDIO, João Antonio Botelho.Nos Confins do Império, um deserto de homens povoado por bois. 1993. Dissertação (Mestrado em História), UFF, Rio de Janeiro.

MAESTRI, Mário; Júlio Quevedo dos Santos; Paulo Esselin (Orgs.). Peões, vaqueiros \& cativos campeiros. Estudos sobre a economia pastoril no Brasil. (TOMO III), 2010.

MAESTRI, Mário; Maria do Carmo Brazil (Orgs.). Peões, vaqueiros \& cativos campeiros.Estudos sobre a economia pastoril no Brasil.(TOMO I), 2009.

MAESTRI, Mário; Solimar Oliveira Lima (Orgs.). Peões, vaqueiros \& cativos campeiros. Estudos sobre a economia pastoril no Brasil.(TOMO II), 2010.

MARTINS, José de Souza. O cativeiro da terra. 2. ed. São Paulo: Ciências Humanas, 1979.

MORENO, Gislaene. Terra e Poder em Mato Grosso. Política e mecanismos de burla-18921992. Cuiabá-MT, Entrelinhas-EdUFMT, 2007.

MOTTA, Márcia Maria Menendes. Nas fronteiras do poder. Conflito e direito à terra no Brasil do século XIX. 2. ed. rev. ampl. Niterói: EdUFF, 2008.

MOTTA, Márcia Maria Menendes. Pelas 'Bandas d'Além'- fronteira fechada e arrendatários escravistas numa região policultora, 1808-1888. 1989. Dissertação (Mestrado em História), UFF, Rio de Janeiro.

MOUTINHO, Joaquim Ferreira. Noticia sobre a Província de Matto Grosso seguida D’um roterio da Viagem de sua Capital a São Paulo. São Paulo: Typographia de Henrique Schroeder, 1869.

OLIVEIRA, Mônica Ribeiro de. Negócios de Família: mercado, terra e poder na formação da cafeicultura mineira (1789-1870). 1999. (Doutorado em História), UFF. 
ORTIZ, Helen Scorsatto. O banquete dos ausentes: A Lei de Terras e a formação do latifúndio no norte do Rio Grande do Sul (Soledade - 1850-1889). 2006. Dissertação (Mestrado em História), UPF, Passo Fundo.

OSÓRIO, Helen. Apropriação da terra no Rio Grande de São Pedro e a formação do espaço platino. 1990. Dissertação (Mestrado), UFRGS.

PEDROZA, Manoela. Engenhocas da Moral: redes de parentela, transmissão de terras e direitos de propriedade na freguesia de Campo Grande (Rio de Janeiro, século XIX). Rio de Janeiro: Arquivo Nacional, 2011.

PENTEADO, Yara (Org.). 'Como se de ventre livre nascido fosse...'.CampoGrande-MS: SEJT-SEEB/MS-Ministério da Cultura-Fundação Palmares/DF, 1993.

PESSOA, Angelo Emílio da Silva Pessoa. As ruínas da tradição: a casa da torre de Garcia D'ávila. Família e propriedade no nordeste coloquial. 2003. (Tese de Doutorado em História Social, FFLCH/USP).

PORTO, José da Costa. O Sistema Sesmarial no Brasil. 2. ed. Brasília. Ed. da UnB, 1979.

Revista História Debates e Tendências, v.7, n.2, jul./dez., 2007. Disponível em: http://www.upf.br/seer/index.php/rhdt Acesso em: 10 de março de 2016.

RUIZ, Ricardo Muniz de. Sistema agrário, demografia da escravidão e família escrava em Itaguay-séc. XIX-1830-1872. 1997. Dissertação (Mestrado em História), UFF.

SABOYA, Vilma Eliza Trindade de. A Lei de Terras (1850) e a política imperial - seus reflexos naProvíncia de Mato Grosso. Revista Brasileira de História. Historiografia propostas e práticas. São Paulo: Contexto, 1995. v. 15, n.30.

SANTOS FILHO, Lycurgo. Uma Comunidade Rural no BrasilAntigo (aspectos da Vida Patriarcal no Sertão da Bahia nos Séculos XVIII e XIX), São Paulo: Nacional, 1956.

SILVA, Adilson Rodrigues. "Sertão" de Coxim: Apossamento de Terras, Conquistas e Relações de Trabalho (1830-1898). Dourados, MS : UFGD, 2013.

SILVA, Ligia Osório. Terras devolutas e Latifúndio: efeitos da lei de 1850. 2. ed. Campinas/SP: EdUnicamp, 2008.

TAUNAY, Alfredo d' Escragnolle. Scenas de Viagem. Exploração entre os rios Taquary e Aquidauana no distrito de Miranda. Memória descriptiva. Rio de Janeiro: Typographia Americana, 1868.

VINHAES, Eliana. Cantagalo - estudo das formas de organização e acumulação de terra e riqueza. 1992. Tese (Doutorado em História), UFRJ. Rio de Janeiro.

VOLPATO, Luiza Rios Ricci. Cativos do sertão: vida cotidiana e escravidão em Cuiabá em 1850-1888. São Paulo: Marco Zero; Cuiabá, MT: EdUFMT, 1993.

WISSENBACH, Maria Cristina Cortez. Desbravamento e catequese na constituição da nacionalidade brasileira: as expedições do barão de Antonina no Brasil Meridional. Revista Brasileira de História, São Paulo, v. 15, n. 30,1995. 